\title{
SINERGITAS BIMBINGAN KONSELING DAN GURU PENDIDIKAN AGAMA ISLAM DALAM PENGEIMBANGAN KARAKTER SISWA DI SMK NEGERI 1 GUNUNGPUTRI
}

\author{
Muhamad Ramdan \\ Universitas Ibn Khaldun Bogor
}

\begin{abstract}
The background of this research is based on the low quality of character of school students in Indonesia which is characterized by many cases of violence against teachers and fellow students. Counseling guidance and Islamic religious education teachers in schools have a profound effect on the character of students, as both share the same responsibility for the character education of students in the school. The quality of the character of students is one of the indicators of the success of the implementation of education. The purpose of this research is to find out how the process or efforts made by counseling guidance and islamic religious education teachers in planting the character values of students in SMK Negeri 1 Gunungputri. This research uses qualitative methods, in which the research process is conducted through interviews with related parties or related to the focus of research. In addition, data collection is also done through observation and documentation. In this study, triangulation techniques became a way of testing the validity of data. The method of data analysis conducted in this study is a qualitative descriptive method in which the findings of the study are compiled, clarified, analyzed, and interpreted in the form of sentences resulting in a conclusion. The results showed positive results on cooperation or synergy conducted by counseling guidance and Islamic religious education teachers in character development through interaction, counseling guidance programs, and school programs related to character education.
\end{abstract}

Keywords: Counseling guidance, Islamic religious education, character development

\section{PENDAHULUAN}

Pendidikan sangat penting dalam kehidupan beragama, bermasyarakat, berbangsa, dan bernegara. Pendidikan sangat berpengaruh terhadap peradaban dunia karena pendidikan adalah sumber utama bagi manusia untuk mengetahui berbagai macam hal, seperti ilmu alam, ilmu hitung, sosial, budaya, ekonomi, politik, hingga militer yang merupakan faktor utama perkembangan peradaban.

Secara sederhana pendidikan dapat dimaknai sebagai usaha untuk membantu peserta didik mengembangkan seluruh potensinya (hati, pikir, rasa dan karsa, serta raga) untuk menghadapi masa depan. ${ }^{1}$ Pengertian tersebut dapat diartikan bahwa pendidikan

\footnotetext{
${ }^{1}$ Muchlas Samani \& Hariyanto, Konsep dan Model Pendidikan Karakter (Bandung: PT REMAJA ROSDAKARYA, 2011), hal. 37
} 
berfungsi untuk membentuk dan mempersiapkan pola pikir, perasaan, sikap dan spiritual, serta raga untuk menghadapi kehidupan di masa yang akan datang.

Dalam Islam, pendidikan mempunyai posisi yang penting. Mufatihatut Taubah (2015:11) menjelaskan bahwa pendidikan dalam kaca mata Islam dimulai dari keluarga untuk membentuk sikap, nilai hidup, pengembangan bakat dan minat, serta pembinaan kepribadian. Penjelasan tersebut dapat diartikan bahwa pendidikan pertama yang dilakukan adalah pendidikan karakter. ${ }^{2}$

Pentingnya pendidikan juga berlaku di Indonesia. Undang-undang telah mengatur tentang sistem pendidikan nasional pada pasal 1 ayat (1) No. 20 Tahun 2003 yang berbunyi:

"Pendidikan adalah usaha sadar dan terencana untuk mewujudkan suasana belajar dan proses pembelajaran agar peserta didik secara aktif mengembangkan potensi dirinya untuk memiliki kekuatan spiritual keagamaan, pengendalian diri, kepribadian, kecerdasan, akhlak mulia, serta keterampilan yang diperlukan dirinya, masyarakat, bangsa dan negara."

Berdasarkan undang-undang tersebut, dapat dipahami bahwa tujuan pendidikan di Indonesia adalah untuk mengembangkan karakter peserta didik. Sebagai upaya perwujudan tujuan pendidikan dimaksud, lembaga dan instansi pendidikan di Indonesia telah menghadirkan bimbingan konseling sebagai salah satu komponen pendidikan yang berkonsentrasi pada aspek kepribadian atau karakter. Hal tersebut seperti dikemukakan oleh Lilis Satriah bahwa bimbingan konseling adalah proses pemberian bantuan kepada siswa atau individu atau suatu kelompok yang dilakukan oleh seorang konselor untuk membantu menyelesaikan masalah klien, agar dapat memahami dirinya, menentukan pilihan, dan dapat menyesuaikan dirinya sesuai dengan kebutuhan. ${ }^{3}$

Selain bimbingan konseling, sekolah memiliki komponen lain yang juga berfungsi untuk membentuk karakter peserta didik. Komponen dimaksud termasuk ke dalam mata pelajaran wajib pada pendidikan di sekolah, yakni pendidikan agama. Pendidikan agama sangat penting untuk membentuk kesadaran beragama yang akan berpengaruh kepada moral dan perilaku. Saat ini pendidikan agama Islam di sekolah dilengkapi dengan pendidikan budi pekerti, dengan nama mata pelajaran baru yaitu "Pendidikan Agama Islam dan Budi Pekerti”. Salah satu fungsi mata pelajaran tersebut adalah pendidikan karakter. Hal tersebut dapat dilihat misalnya dalam buku "Pendidikan Agama Islam dan Budi Pekerti Kelas 2 Kurikulum 2013 Edisi Revisi 2017”, "Pendidikan Agama Islam dan Budi Pekerti Kelas 3 Kurikulum 2013 Edisi Revisi 2018”, dan "Pendidikan Agama Islam dan Budi Pekerti Kelas 10 SMA/SMK Kurikulum 2013”.

\footnotetext{
${ }^{2}$ Mufatihatut Taubah, Pendidikan Anak dalam Keluarga Perspektif Islam, Jurnal Pendidikan Agama Islam, Vol. 03. No. 1, 2015, hal. 11

${ }^{3}$ Lilis Satriah, Panduan Bimbingan dan Konseling Pendidikan (Bandung: FOKUSMEDIA, 2018), hal. 32
} 
Dalam Kamus Besar Bahasa Indonesia (KBBI) karakter disebut juga dengan watak yang dapat mempengaruhi perilaku. Perilaku dan budi pekerti yang tidak dibentuk dari pendidikan karakter yang baik akan mengakibatkan permasalahan hingga melahirkan berbagai macam kasus kejahatan seperti tindak kekerasan, perundungan, pelecehan, dan lain-lain. Oleh karena itu, pendidikan karakter dinilai sangat penting dan harus dikembangkan.

Pada Maret 2018, terjadi kasus yang menunjukkan rendahnya perilaku dan budi pekerti siswa di Indonesia. Seorang guru Sekolah Menengah Pertama (SMP) Darussalam, Kecamatan Pontianak Timur, Nuzul Kurniawati menjadi korban penganiayaan yang dilakukan oleh muridnya sendiri. Berdasarkan berita dari situs regional.kompas.com yang diterbitkan pada Kamis, 8 Maret 2018, murid berinisial NF berani memukul gurunya dengan kursi. Kejadian tersebut bermula ketika pelaku bermain telepon seluler saat jam pelajaran berlangsung. Guru yang mengajar pada saat itu menegurnya, namun tidak digubris, sehingga guru lain yang melihat kejadian itu ikut membantu menegur murid tersebut. Tidak terima atas teguran itu, pelaku akhirnya memukul guru tersebut dengan kursi plastik.

Kasus lain yang juga menunjukkan bahwa pendidikan karakter di Indonesia harus ditingkatkan adalah kasus bully yang dilakukan oleh murid kepada guru di Sekolah Menengah Pertama (SMP) PGRI Weininginanom, Gresik, Jawa Timur. Berdasarkan berita dari m.detik.com yang ditulis pada Senin, 11 Februari 2019, seorang siswa menantang gurunya dengan memegang kepala guru, mendorong, dan mencengkram kerah bajunya seakan-akan hendak memukul guru tersebut sambil memaki. Kasus-kasus tersebut menunjukkan bahwa tujuan pendidikan di Indonesia yakni pengembangan karakter di beberapa sekolah belum tercapai.

Komponen yang mempunyai peran utama dalam pendidikan karakter di sekolah adalah bimbingan konseling dan pendidikan agama Islam. Program yang dilaksanakan oleh bimbingan konseling serta upaya dari guru pendidikan agama Islam harus menunjukkan sinergi dalam pendidikan karakter siswa di sekolah. Hal tersebut akan bepengaruh terhadap kualitas pengembangan karakter peserta didik.

Permasalahan bimbingan konseling yang sering terjadi adalah pemahaman peserta didik terhadap bimbingan konseling. Bimbingan konseling dianggap sebagai tempat menangani peserta didik yang nakal dan bermasalah. Guru bimbingan konseling identik dengan galak, garang, dan ditakuti peserta didik. ${ }^{4}$ Permasalahan tersebut harus ditangani oleh guru bimbingan konseling untuk mengubah pandangan peserta didik terhadap bimbingan konseling, sehingga bimbingan konseling dapat menjalankan peran sebagaimana mestinya.

\footnotetext{
${ }^{4}$ Heldayani Bumasyaril, Persepsi Peserta Didik terhadap Pelaksanaan Bimbingan Konseling di Sekolah Menengah Atas Negeri 1 Karya Penggawa Pesisir Barat, Jurnal Bimbingan Konseling, 2016, hal.13
} 
Pendidikan agama Islam di sekolah juga memiliki permasalahan. Permasalahan internal yang terjadi pada pendidikan agama Islam di sekolah misalnya guru yang belum berkompeten, atau sarana dan prasarana yang tidak mendukung. ${ }^{5}$ Guru pendidikan agama Islam harus meningkatkan kompetensinya agar dapat menjalankan tugas dan peran dalam pengembangan karakter peserta didik dengan baik.

Upaya untuk mengimplementasikan serta mengembangkan pendidikan karakter telah dilakukan oleh Sekolah Menengah Kejuruan (SMK) Negeri 1 Gunungputri, Kabupaten Bogor. Sekolah tersebut merupakan sekolah menengah kejuruan pertama yang didirikan di Kabupaten Bogor dan berhasil menjadi sekolah menengah kejuruan terbaik ke empat tahun 2019 menurut Kementerian Pendidikan dan Kebudayaan (Badrun, blog.kartunmania,com/2019/10/daftar-peringkat-smk-terbaik-kabupaten-bogor-th-

2019/akses 28 Oktober 2019). Berdasarkan informasi dari media jurnalisme kompasiana.com yang ditulis oleh mahasiswa Institut Pertanian Bogor (IPB), Sarah Sabila dan diterbitkan pada 6 Maret 2019, Wakil Kepala Sekolah Kurniawan mengatakan bahwa setiap pekan peserta didik melakukan kegiatan seperti tausyiah, olahraga bersama, dan kegiatan bersih-bersih secara terjadwal. Hal tersebut dilakukan sebagai upaya penanaman nilai-nilai karakter dalam diri peserta didik.

Upaya pengembangan karakter siswa di SMK Negeri 1 Gunungputri juga dilakukan dengan membentuk sebuah badan yang mempunyai fokus di bidang kedisiplinan, yaitu Gerakan Disiplin Siswa (GDS). Berdasarkan wawancara kepada Muhammad Yudha Gutara selaku guru bimbingan konseling pada Jum'at, 24 Januari 2020 di SMK Negeri 1 Gunungputri, GDS merupakan program sekolah yang bertugas dalam penanaman nilainilai karakter peserta didik.

Pendidikan karakter di SMK Negeri 1 Gunungputri terus diupayakan, tetapi juga memiliki masalah. Program-program pendidikan karakter yang dilaksanakan sekolah tidak sepenuhnya berhasil membentuk kepribadian peserta didik. Hal tersebut diketahui berdasarkan wawancara yang penulis lakukan terhadap dua orang siswa pada Senin, 27 Januari 2020 di SMK Negeri 1 Gunungputri. Siswa bernama Budiyana dan Muhammad Bintang Pratama mengatakan bahwa masih banyak peserta didik yang melanggar peraturan seperti datang terlambat, rambut yang tidak sesuai aturan, bahkan salah satu peserta didik dikatakan dengan berani mengancam guru saat sedang dirazia rambut. Permasalahan tersebut membuktikan bahwa pendidikan karakter tidak cukup berhasil jika hanya bergantung pada program tertentu, pendidikan karakter juga harus ditunjang dengan kerja sama antar komponen pendidikan di sekolah.

Kerja sama antar komponen pendidikan dalam pendidikan karakter di sekolah bisa dilakukan oleh bimbingan konseling dan guru pendidikan agama Islam, karena kedua komponen tersebut memiliki fokus dan tujuan yang sama yaitu pendidikan karakter. Penulis tertarik untuk melakukan penelitian terhadap program sinergis antara bimbingan

\footnotetext{
${ }^{5}$ Sopian Sinaga, Problematika Pendidikan Agama Islam di Sekolah dan Solusinya, Jurnal Pendidikan Agama Islam, Vol. 2 No. 1, 2017, hal.183
} 
konseling dengan upaya guru pendidikan agama Islam terhadap pendidikan karakter siswa di SMK Negeri 1 Gunungputri. Oleh karena itu, penelitian ini penulis beri judul, "Sinergitas Bimbingan Konseling dan Guru Pendidikan Agama Islam dalam Pengembangan Karakter Siswa di SMK Negeri 1 Gunungputri”.

\section{METODE PENELITIAN}

Penelitian ini menggunakan pendekatan kualitatif, dimana penelitian dilakukan untuk memahami suatu fenomena, kejadian, maupun kehidupan manusia dengan terlibat langsung atau tidak langsung dalam setting yang diteliti, kontekstual dan menyeluruh. ${ }^{6}$ Penelitian kualitatif adalah suatu strategi inquiry yang menekankan pencarian makna, pengertian, konsep, karakteristik, gejala, simbol, maupun deskripsi tentang suatu fenomena; fokus dan multimetode, bersifat alami dan holistik; mengutamakan kualitas, menggunakan beberapa cara, serta disajikan secara naratif. ${ }^{7}$

Penelitian kualitatif merupakan jenis penelitian yang temuan-temuannya tidak diperoleh melalui prosedur kuantifikasi, perhitungan statistik, atau bentuk cara-cara lainnya yang menggunakan angka. Penelitian kualitatif pada prinsipnya dilakukan untuk memahami objek yang diteliti secara mendalam. Tujuan penelitian kualitatif pada umumnya mencakup informasi tentang fenomena utama yang dieksplorasi dalam penelitian, partisipan penelitian dan lokasi penelitian. ${ }^{8}$

Dalam penelitian kualitatif, peneliti berfungsi sebagai instrumen kunci yang melakukan observasi, membuat catatan, dan melakukan wawancara. Alat-alat seperti angket atau kuisioner, tes, skala penilaian tidak lazim digunakan. Alat bantu yang digunakan terkait dengan objek penelitian, antara lain: alat rekam seperti video, tustel, tape, kamera, dan sebagainya, sedangkan peneliti merupakan instumen kunci.

Karakteristik penelitian kualitatif menurut Bogdan dan Biklen dalam Sugiyono yang dikutip oleh Rukajat adalah sebagai berikut:

1. Penelitian kualitatif dilakukan pada kondisi yang alamiah, langsung ke sumber data dan peneliti adalah instrumen kunci;

2. Penelitian kualitatif lebih bersifat deksriptif. Data yang terkumpul terbentuk kata-kata atau gambar, sehingga tidak menekankan pada angka;

3. Penelitian kualitatif lebih menekankan pada proses daripada produk atau outcome;

4. Penelitian kualitatif melakukan analisis data secara induktif;

5. Penelitian kualitatif lebih menekankan makna (data di balik yang teramati). ${ }^{9}$

Michael Quinn Patton dalam Yusuf (2019:336) mengemukakan bahwa karakteristik utama penelitian kualitatif yaitu: (1) penyelidikan bersifat naturalistik; (2)

\footnotetext{
${ }^{6}$ A. Muri Yusuf, Metode Penelitian Kuantitatif, Kualitatif \& Penelitian Gabungan, (Jakarta: PRENAMEDIA GROUP) 2019, hal. 328

${ }^{7}$ Ibid, hal. 329

${ }^{8}$ Ajar Rukajat, Pendekatan Penelitian Kualitatif(Qualitative Research Approach), (Yogyakarta: Penerbit Deepublish) 2018, hal. 4

${ }^{9}$ Ibid, hal. 13
} 
analisis bersifat induktif; (3) holistik; (4) data bersifat kualitatif; (5) menekankan pemahaman dan kontak personal; (6) dinamis; (7) setiap kasus unik dan spesifik; (8) dalam konteksnya, netral dan bersifat sensitif; serta (9) rancangan bersifat fleksibel.

Penelitian kualitatif mengungkapkan data secara kualitatif dan disajikan secara naratif. Cakupan data dalam penelitian kualitatif sebagaimana dikemukakan oleh Yusuf adalah sebagai berikut:

1. Deskripsi yang mendetail tentang situasi, kegiatan, atau peristiwa maupun fenomena tertentu, baik menyangkut manusianya maupun hubungannya dengan manusia lainnya.

2. Pendapat langsung dari orang-orang yang telah berpengalaman, pandangannya, sikapnya, kepercayaan serta jalan pikirannya.

3. Cuplikan dari dokumen, dokumen laporan, arsip dan sejarahnya.

4. Deskripsi yang mendetail tentang sikap dan tingkah laku seseorang. ${ }^{10}$

Penelitian yang menilai dan mendeskripsikan sinergitas program bimbingan konseling serta upaya guru pendidikan agama Islam dalam pengembangan karakter siswa relevan dengan pendekatan kualitatif, mengingat bahwa metode kualitatif lebih menekankan pada proses serta mengutamakan kualitas. Di samping itu, penelitian kualitatif menekankan pada pemahaman dan kontak personal serta memberikan deskripsi mendalam tentang sikap. Penelitian ini juga bersifat natural sehingga hasil penelitian disimpulkan apa adanya dan mewakili persepsi informan atau narasumber terhadap objek penelitian.

Penentuan sumber data dilakukan dengan cara Purposive Samping (sampel diambil secara purposif), yaitu penentuan informasi yang dilandasi tujuan atau pertimbangan tertentu. ${ }^{11}$ Oleh karena itu, dalam penelitian ini penentuan sumber data dilandasi dengan tujuan menggali informasi secara mendalam dari informan yang berkompeten dan mempunyai relevansi dengan penelitian.

Berdasarkan tujuan dan pertimbangan tersebut, maka dapat ditentukan sumber data dari penelitian ini adalah guru bimbingan konseling, guru pendidikan agama Islam, dan peserta didik SMK Negeri 1 Gunungputri. Di samping itu, dapat ditambahkan sumber data lainnya seperti kepala sekolah, guru mata pelajaran di luar pendidikan agama Islam, dan karyawan di SMK Negeri 1 Gunungputri untuk memperkuat temuan penelitian sehingga memiliki tingkat validitas yang tinggi.

Teknik pengumpulan data dalam metode kualitatif adalah wawancara, observasi, dan studi dokumentasi. Ketiga teknik tersebut dapat dijelaskan sebagai berikut:

1. Teknik Wawancara

Wawancara merupakan salah satu teknik yang dapat digunakan untuk mengumpulkan data penelitian. Wawancara secara sederhana dapat diartikan sebagai

\footnotetext{
${ }^{10}$ A. Muri Yusuf, Metode Penelitian Kuantitatif, Kualitatif \& Penelitian Gabungan, (Jakarta: PRENAMEDIA GROUP) 2019, hal. 331

${ }^{11}$ Ibid, hal. 369
} 
proses interaksi antara pewawancara dan sumber informasi atau orang yang diwawancarai secara langsung. ${ }^{12}$

Wawancara dilakukan bersama informan yang berkompeten dan relevan dengan penelitian, yaitu guru bimbingan konseling, guru pendidikan agama Islam, dan sejumlah peserta didik di SMK Negeri 1 Gunungputri. Sebelum memulai wawancara, peneliti menjelaskan terlebih dahulu mengenai permasalahan penelitian dan pedoman yang dilakukan selama kegiatan wawancara berlangsung. Proses wawancara dilakukan dengan perlengkapan alat rekam guna memperoleh hasil wawancara yang akurat dan mencegah kehilangan informasi.

\section{Teknik Observasi}

Observasi atau pengamatan merupakan aktivitas yang sistematis terhadap gejalagejala yang bersifat fisikal maupun mental. ${ }^{13}$ Observasi merupakan salah satu teknik yang dapat digunakan untuk mengetahui atau meneliti tingkah laku non verbal (Yusuf, 2019:384). ${ }^{14}$

Observasi yang dilakukan dalam penelitian ini berbentuk Non-participation Observer, yakni suatu bentuk observasi di mana peneliti tidak terlibat langsung dalam kegiatan kelompok, atau dapat juga dikatakan penulis tidak ikut serta dalam kegiatan yang diamatinya. ${ }^{15}$ Observasi dilakukan dengan mengamati program yang dilaksanakan oleh bimbingan konseling dan proses pengajaran yang dilakukan oleh guru di SMK Negeri 1 Gunungputri. Selanjutnya, peneliti mengamati perilaku peserta didik selama proses penelitian.

\section{Studi Dokumentasi}

Dokumen tentang orang atau sekelompok orang, peristiwa dalam situasi yang sesuai dan terkait dengan fokus penelitian merupakan sumber informasi yang sangat berguna dalam penelitian kualitatif. Dokumen tersebut dapat berbentuk teks tertulis, artefact, gambar, maupun foto. Dokumen tertulis dapat pula berupa sejarah kehidupan, biografi, karya tulis, atau cerita. ${ }^{16}$

Peneliti dapat menerima data dari informan mengenai fokus penelitian dengan metode studi dokumentasi. Sumber tertulis, foto, ataupun video yang didapat dari informan mengenai proses pengembangan karakter di SMK Negeri 1 Gunungputri dapat menjadi data yang valid dan tidak diragukan.

Keakuratan, keabsahan, dan kebenaran data yang dikumpulkan dan dianalisis sejak awal penelitian menjadi penentu kebenaran dan ketepatan hasil penelitian sesuai dengan

\footnotetext{
${ }^{12}$ Ibid, hal. 372

${ }^{13}$ Ajar Rukajat, Pendekatan Penelitian Kualitatif (Qualitative Research Approach), (Yogyakarta: Penerbit Deepublish) 2018, hal. 22

${ }^{14}$ A. Muri Yusuf, Metode Penelitian Kuantitatif, Kualitatif \& Penelitian Gabungan, (Jakarta: PRENAMEDIA GROUP) 2019, hal.384

${ }^{15}$ Ibid

${ }^{16}$ Ibid, hal. 391
} 
masalah dan fokus penelitian. ${ }^{17}$ Dalam penelitian ini, penulis menggunakan triangulasi untuk menguji keabsahan data.

Triangulasi adalah salah satu teknik dalam pengumpulan data untuk mendapatkan temuan dan interpretasi data yang akurat dan kredibel dengan menggunakan sumber informasi yang lebih banyak. ${ }^{18}$ Dalam penelitian kualitatif, teknik triangulasi dapat dimanfaatkan sebagai pemeriksaan keabsahan data yang ditemukan dari hasil wawancara, observasi, dan dokumentasi. Informasi yang memperkuat temuan penelitian bisa didapatkan melalui wawancara dengan informan lainnya yang memiliki keterkaitan dengan fokus masalah untuk menguji kredibilitas data, sehingga hasil penelitian bisa mencapai validitas tinggi.

Dalam penelitian ini, langkah awal yang dilakukan adalah melakukan wawancara kepada guru Bimbingan Konseling dan guru Pendidikan Agama Islam, serta siswa SMK Negeri 1 Gunungputri terkait dengan pengembangan karakter siswa. Setelah itu, dilakukan pengamatan terhadap program Bimbingan Konseling dan guru Pendidikan Agama Islam dalam pengembangan karakter peserta didik yang kualitasnya dibuktikan melalui profesionalitas program dan perilaku peserta didik. Selanjutnya, triangulasi dilakukan dengan menggunakan sumber data yang lain, seperti melakukan diskusi lebih lanjut kepada Kepala Sekolah, Waka Kesiswaan, guru mata pelajaran di luar Pendidikan Agama Islam, atau kepada petugas keamanan dan kebersihan untuk memastikan kebenaran hasil temuan.

Teknik analisis data dalam penelitian ini menggunakan Model Spradley, yaitu teknik analisis data yang dikemukakan oleh James Spradley pada tahun 1980. Prosedur penelitian etnografis Spradley mencakup (1) menetapkan informan; (2) melakukan wawancara terhadap informan; (3) membuat catatan etnografis; (4) mengajukan pertanyaan deskriptif; (5) melakukan analisis wawancara etnografis; (5) membuat analisis domain; (7) mengajukan pertanyaan struktural; (8) membuat analisis taksonomi; (9) mengajukan pertanyaan kontras; (9) membuat analisis komponensial; (11) menemukan tema budaya; dan (12) menulis etnografi. ${ }^{19}$

Model Spradley mencakup lima tahap analisis data, yaitu (1) analisis wawancara etnografis; (2) analisis domain; (3) analisis taksonomi; (4) analisis komponensial; (5) analisis tema. Lima tahap tersebut dideskripsikan sebagai berikut:

\section{Analisis Wawancara Etnografis}

Analisis wawancara etnografis merupakan pengamatan terhadap berbagai hal yang telah dikonseptualisasikan oleh informan sebelumnya untuk menemukan masalah yang selanjutnya ditanyakan pada saat wawancara selanjutnya. ${ }^{20}$ Pada penelitian ini, wawancara etnografis dilakukan kepada beberapa siswa SMK Negeri 1 Gunungputri

\footnotetext{
${ }^{17}$ Ibid, hal. 394

${ }^{18}$ Ibid, hal. 395

${ }^{19}$ Ibid, hal. 410

${ }^{20}$ Ibid
} 
untuk mengetahui gambaran umum mengenai program dan upaya yang dilakukan oleh Bimbingan Konseling dan guru Pendidikan Agama Islam dalam pengembangan karakter peserta didik, serta masalah karakter peserta didik di SMK Negeri 1 Gunungputri.

\section{Analisis Domain}

Analisis domain adalah analisis yang dilakukan untuk memperoleh gambaran umum dari objek penelitian yang diperoleh dari hasil wawancara etnografis. ${ }^{21}$ Analisis domain dalam penelitian ini dilakukan untuk menemukan dan menetapkan berbagai domain dan kategori tertentu sebagai kesimpulan awal. Setelah hasil dari analisis domain ditemukan, penulis dapat menyusun pedoman wawancara yang berisi pertanyaan kepada informan kunci tentang pengembangan karakter siswa di SMK Negeri 1 Gunungputri.

\section{Analisis Taksonomi}

Analisis taksonomi adalah menjabarkan domain yang dipilih menjadi lebih rinci ntuk mengetahui struktural internalnya, tahap ini dilakukan melalui observasi dan wawancara terseleksi. ${ }^{22}$ Dalam penelitian ini, analisis taksonomi dilakukan dengan wawancara terhadap informan kunci, yaitu guru Bimbingan Konseling, guru Pendidikan Agama Islam, dan siswa di SMK Negeri 1 Gunungputri terkait dengan program dan upaya pengembangan karakter siswa. Selain itu, wawancara juga dilakukan kepada Kepala Sekolah, Waka Kesiswaan, petugas kebersihan dan keamanan, serta informan lain yang dapat memperkuat hasil penelitian. Selanjutnya, untuk mengetahui kualitas program dan upaya Bimbingan Konseling dan guru Pendidikan Agama Islam dalam pengembangan karakter siswa, dilakukan observasi terhadap program dan upaya yang dijalankan Bimbingan Konseling dan guru Pendidikan Agama Islam serta perilaku siswa sehari-hari di lingkungan sekolah.

\section{Analisis Komponensial}

Analisis komponensial merupakan tahap pencarian temuan-temuan spesifik pada setiap struktur internal dengan mengontraskan antar-elemen. ${ }^{23}$ Dalam penelitian ini, akan ditemukan secara spesifik perbedaan dalam setiap dimensi melalui tahap analisis komponensial. Tahap ini dapat menjadi pembuktian informasi pada informan dan mengisi informasi yang kurang serta menghasilkan sejumlah data keseluruhan yang kemudian dapat diinterpretasikan ke dalam suatu kesimpulan.

\section{Analisis Tema Budaya}

Analisis Tema Budaya merupakan kegiatan analisis bagian akhir sebelum peneliti menulis etnografi sebagai produk akhir penelitian, yaitu mencari hubungan di antara domain secara keseluruhan serta dikaitkan dengan tema-tema budaya secara keseluruhan yang menjadi fokus penelitian. ${ }^{24}$ Dalam penelitian ini, hasil temuan yang didapatkan disimpulkan oleh penulis dengan cara menghubung-hubungkan dan mereka-reka secara
${ }^{21}$ Ibid
${ }^{22}$ Ibid
${ }^{23} \mathrm{Ibid}$
${ }^{24}$ Ibid 
rasio agar dapat terlihat gambaran secara utuh dan menyeluruh data yang telah terkumpul. Data yang telah disimpulkan menunjukkan tingkat kualitas sinergi Bimbingan Konseling dan guru Pendidikan Agama Islam dalam upaya pengembangan karakter siswa di SMK Negeri 1 Gunungputri.

\section{KAJIAN TEORI}

\section{A. Pengertian Bimbingan Konseling}

Dalam Kamus Besar Bahasa Indonesia (KBBI), secara bahasa "bimbingan" berarti cara mengerjakan sesuatu atau tuntunan. Kemudian, kata "konseling" merupakan pemberian bimbingan oleh ahli kepada seseorang dengan menggunakan metode psikologis dan sebagainya (Tim Penyusun, 2019). ${ }^{25}$

Menurut Syamsu Yusuf, bimbingan dan konseling merupakan terjemahan dari kata "guidance" dan "counseling" dalam bahasa Inggris. Istilah "guidance” berasal dari akar kata "guide”, yang memiliki arti: (1) mengarahkan, (2) memandu, (3) mengelola, dan (4) menyetir. ${ }^{26}$

Selanjutnya menurut Robert D. Myrick, istilah "guidance” (bimbingan) merupakan proses bantuan yang difokuskan kepada perkembangan yang bersifat umum, terkait dengan kebutuhan, minat, sikap, dan tingkah laku peserta didik. Robert D. Myrick mengemukakan perbedaan antara bimbingan dan konseling. Menurutnya, bimbingan adalah seperangkat layanan yang bersifat umum (generik) bagi perkembangan pribadi peserta didik, sedangkan konseling adalah salah satu layanan bimbingan tersebut. American School Counselor Association (ASCA) mengemukakan bahwa konseling adalah hubungan tatap muka yang bersifat rahasia, penuh dengan sikap penerimaan dan pemberian kesempatan dari konselor kepada klien. Konselor mempergunakan keterampilannya untuk membantu kliennya mengatasi masalah-masalahnya. ${ }^{27}$

Menurut Heru Sriyono, secara istilah bimbingan merupakan proses pemberian bantuan kepada individu agar dapat belajar memahami diri dan lingkungannya. ${ }^{28} \mathrm{Di}$ samping itu, Dewa Ketut Sukardi dan Desak P.E Nila Kusumawati yang dikutip oleh Lilis Satriah mengemukakan bahwa bimbingan adalah proses pemberian bantuan yang dilakukan secara terus menerus dan sistematis dari pembimbing kepada yang dibimbing. ${ }^{29}$ Proses bimbingan tersebut bertujuan agar individu yang dibimbing dapat mencapai kemandirian dalam pemahaman diri, penerimaan diri, perkembangan yang optimal, dan

\footnotetext{
25 Tim Penyusun, Kamus Besar Bahasa Indonesia, (Jakarta: Badan Pengembangan Bahasa dan Perbukuan, Kementerian Pendidikan dan Kebudayaan Indonesia) 2016-2019

${ }^{26}$ Syamsu Yusuf, Bimbingan dan Konseling Perkembangan: Suatu Perkembangan Komprehensif (Bandung: PT Refika Aditama) 2017, hal. 31

${ }^{27}$ Ibid, hal. 31-33

${ }^{28}$ Heru Sriyono, Bimbingan dan Konseling Belajar Bagi Siswa di Sekolah (Depok: PT Raja Grafindo Persada) 2015, hal. 11

${ }^{29}$ Lilis Satriah, Panduan Bimbingan dan Konseling Pendidikan (Bandung: FOKUSMEDIA) 2018, hal.13
} 
penyesuaian diri terhadap lingkungan, sementara konseling merupakan bagian dari bimbingan yang bersifat pelayanan atau teknik.

Berdasarkan beberapa pengertian yang diuraikan di atas, dapat dipahami bahwa terdapat perbedaaan antara bimbingan dan konseling. Bimbingan diartikan sebagai sebuah proses pemberian bantuan yang dilakukan oleh seorang ahli kepada individu untuk memahami dan mengembangkan dirinya, sementara konseling merupakan salah satu metode dari bimbingan tersebut. Maka dapat diartikan bahwa bimbingan konseling merupakan proses pemberian bantuan sistematis dan komprehensif yang dilakukan oleh seorang ahli kepada individu dalam aspek kepribadian agar dapat memahami, mengembangkan, dan menyesuaikan diri sesuai kebutuhan.

B. Tujuan Bimbingan Konseling Pendidikan

Tujuan bimbingan konseling pendidikan adalah segala sesuatu yang diharapkan atas dilaksanakannya kegiatan bimbingan konseling dalam satuan pendidikan. Sebelum diuraikan mengenai tujuan bimbingan konseling pendidikan, perlu diketahui bahwa bimbingan konseling pendidikan termasuk ke dalam bimbingan konseling perkembangan. Penggunaan istilah perkembangan didasarkan kepada beberapa alasan yang dikemukakan oleh Robert D Myrick yang dikutip oleh Yusuf sebagai berikut:

1. Perkembangan manusia merupakan proses kehidupan fisiologis, psikologis, sosial, dan moral-spiritual dari sejak lahir sampai mati.

2. Perkembangan melibatkan interaksi antara faktor genetika atau pembawaan dengan lingkungan dimana manusia hidup dan berkembang.

3. Perkembangan manusia merupakan perjalanan hidup dari mulai lahir sampai mati, dimana terjadi proses perubahan kepribadian.

4. Perkembangan merupakan istilah yang pada umumnya digunakan untuk menggambarkan perubahan yang teratur.

5. Lembaga-lembaga sosial dan dimenasi kebudayaan mempengaruhi proses dan tahapan kehidupan individu.

Berdasarkan beberapa alasan tersebut, penulis menyimpulkan bahwa bimbingan konseling pendidikan termasuk ke dalam aspek yang dimaksud dengan bimbingan konseling perkembangan. Tujuan bimbingan konseling perkembangan tersebut dapat dibagi pada tiga aspek, yaitu aspek pribadi-sosial, akademik, dan karir. Menurut Ulul Azam, Bimbingan konseling perkembangan berdasarkan aspek pribadi-sosial memiliki tujuan sebagai berikut:

1. Memiliki komitmen yang kuat dalam mengamalkan nilai-nilai keimanan dan ketaqwaan kepada Tuhan Yang Maha Esa, baik dalam kehidupan pribadi, keluarga, pergaulan, dengan teman sebaya, sekolah, tempat kerja, maupun masyarakat pada umumnya.

2. Memiliki sikap toleransi terhadap umat beragama lain dan saling menghormati, memelihara hak dan kewajibannya masing-masing. 
3. Memiliki pemahaman tentang irama kehidupan yang bersifat fluktuatif antara yang menyenangkan (anugerah) dan yang tidak menyenangkan (musibah), serta mampu meresponnya secara positif sesuai dengan ajaran agama yang dianut.

4. Memiliki pemahaman dan penerimaan diri secara objektif dan konstruktif baik yang terkait dengan keunggulan maupun kelemahan baik fisik maupun psikis.

5. Memiliki sikap positif atau respek terhadap diri sendiri dan orang lain.

6. Memiliki kemampuan untuk melakukan pilihan secara sehat.

7. Bersikap respek terhadap orang lain, menghormati atau menghargai orang lain, tidak melecehkan martabat atau harga dirinya.

8. Memiliki rasa tanggung jawab, yang diwujudkan dalam bentuk hubungan persahabatan, persaudaraan, atau silaturahmi dengan sesama manusia.

9. Mamiliki kemampuan dalam menyelesaikan konflik (masalah) baik bersifat internal (dalam diri sendiri) maupun dengan orang lain.

10. Memiliki kemampuan untuk mengambil keputusan secara efektif.30

Tujuan bimbingan konseling dalam aspek pribadi-sosial di atas bermakna bahwa bimbingan konseling difokuskan pada pembentukan nilai-nilai keimanan dan ketakwaan kepada Tuhan Yang Maha Esa, etika terhadap sesama manusia, dan sikap terhadap masalah yang dialami peserta didik. Selanjutnya, tujuan bimbingan konseling berdasarkan aspek akademik yaitu agar peserta didik memenuhi kriteria kepribadian sebagai berikut:

1. Memiliki kesadaran tentang potensi diri dalam aspek belajar dan memahami berbagai hambatan yang mungkin muncul dalam proses belajar yang dialaminya.

2. Memiliki sikap dan kebiasaan belajar yang positif, seperti kebiasaan membaca buku, disiplin dalam belajar, mempunyai perhatian terhadap semua pelajaran, dan aktif mengikuti semua kegiatan belajar yang diprogramkan.

3. Memiliki motif yang tinggi untuk belajar sepanjang hayat.

4. Memiliki keterampilan untuk menetapkan tujuan dan perencanaan pendidikan, seperti membuat jadwal belajar, mengerjakan tugas-tugas, memantapkan diri dalam memperdalam pelajaran tertentu, dan berusaha memperoleh informasi tentang berbagai hal dalam rangka mengembangkan wawasan yang lebih luas.

5. Memiliki kesiapan mental dan kemampuan untuk menghadapi ujian.

Berdasarkan tujuan bimbingan konseling dalam aspek akademik di atas, dapat dipahami bahwa bimbingan konseling memiliki tujuan untuk membentuk sikap peserta didik dalam menjalankan program belajarnya di sekolah. Kemudian berdasarkan aspek karir, bimbingan konseling perkembangan diharapkan dapat memberikan manfaat kepada peserta didik sebagai berikut:

${ }^{30}$ Ulul Azam, Bimbingan dan Konseling Perkembangan di Sekolah Teori dan Praktik (Yogyakarta: Penerbit Deepublish) 2016, hal. 56-59 
1. Memiliki pemahaman diri (kemampuan, minat, dan kepribadian) yang terkait dengan pekerjaan.

2. Memiliki pengetahuan mengenai dunia kerja dan informasi karir yang menunjang kematangan komptensi karir.

3. Memiliki sikap positif terhadap dunia kerja, memahami relevansi kompetensi belajar (kemampuan menguasai pelajaran) dengan persyaratan keahlian atau keterampilan bidang pekerjaan yang menjadi cita-cita karirnya di masa depan.

4. Mamiliki kemampuan untuk membentuk identitas karir, dengan cara mengenali ciri-ciri pekerjaan, kemampuan (persyaratan) yang dituntut, lingkungan sosiopsikologis pekerjaan, prospek kerja, dan kesejahteraan kerja.

5. Memiliki kemampuan merencanakan masa depan, yaitu merancang kehidupan secara rasional untuk memperoleh peran-peran yang sesuai dengan minat, kemampuan, dan kondisi kehidupan sosial ekonomi.

6. Dapat membentuk pola-pola karir, yaitu kecenderungan arah karir. Apabila seorang siswa bercita-cita menjadi guru, maka dia senantiasa harus mengarahkan dirinya kepada kegiatan-kegiatan yang relevan dengan karir keguruan tersebut.

7. Mengenal keterampilan, kemampuan dan minat. Keberhasilan atau kenyamanan dalam suatu karir amat dipengaruhi oleh kampuan dan minat yang dimiliki.

8. Memiliki kemampuan atau kematangan untuk mengambil keputusan karir. ${ }^{31}$

Tujuan bimbingan konseling dalam aspek karir di atas bermakna bahwa bimbingan konseling juga memberikan bantuan kepada peserta didik dalam menemukan minat, bakat, dan potensinya sehingga dapat memastikan identitas karirnya di masa depan.

Pemaparan tujuan bimbingan konseling perkembangan yang disebutkan di atas bermakna bahwa secara umum tujuan bimbingan konseling tersebut difokuskan pada pemahaman dan pengembangan diri sesuai dengan aspek pribadi-sosial, akademik, dan karir. Jika peserta didik mampu mengimpelementasikan tujuan bimbingan konseling tersebut dalam kehidupannya, maka tujuan bimbingan konseling dapat dikatakan berhasil.

C. Pengertian Pendidikan Agama Islam

Pendidikan berarti "proses pengubahan sikap dan tata laku seseorang atau kelompok dalam usaha mendewasakan manusia melalui upaya pengajaran dan pelatihan. Sementara itu, Islam berarti "agama yang diajarkan oleh Nabi Muhammad SAW berpedoman pada kitab suci al-Qur'an yang diturunkan ke dunia melalui wahyu Allah. ${ }^{32}$

${ }^{31}$ Ulul Azam, Bimbingan dan Konseling Perkembangan di Sekolah Teori dan Praktik (Yogyakarta: Penerbit Deepublish) 2016, hal. 56-59

${ }^{32}$ Halid Hanafi; La Adu; Zainuddin, Ilmu Pendidikan Islam (Yogyakarta: Penerbit Deepublish) 2018, hal.36 
Menurut Arifin, pendidikan Islam adalah studi tentang sistem dan proses kependidikan yang berdasarkan Islam untuk mencapai produk atau tujuannya, baik secara teoritis maupun praktek. ${ }^{33}$

Selanjutnya menurut Muhaimin dalam Mukarromah, secara istilah pendidikan Islam dapat dipahami dalam beberapa pengertian, yaitu pendidikan menurut Islam atau pendidikan Islami, pendidikan keislaman atau pendidikan agama Islam, dan pendidikan dalam Islam. ${ }^{34}$ Muhaimin menjelaskan visi pendidikan Islam dan perwujudan pendidikan Islam sebagai berikut:

Dalam realitasnya pendidikan menurut Islam atau pendidikan Islam terdapat beberapa visi yaitu;

1. Pemikiran, teori, dan praktik penyelenggaraannya melepaskan diri atau kurang mempertimbangakan situasi kongkrit dinamika perkumpulan masyarakat muslim (era klasik dan kontemporer) yang mengintarinya

2. Pemikiran, teori dan praktek, penyelenggaraannya hanya mempertimbangkan pengalaman dan khasanah intelektual ulama klasik

3. Pemikiran, teori, dan praktek penyelenggaraannya hanya mempertimbangakan situasi sosio-historis dan kultur masyarakat kontemporer dan melepaskan diri dari pengalaman-pengalaman serta khasanah intelektual ulama klasik

4. Pemikiran, teori dan praktek penyelenggaraannya mempertimbangkan pengalaman dan khasanah intelektual muslim klasik serta mencermati situasi sosio-historis dan kultur masyarakat kontemporer.

Adapun pendidikan keislaman atau pendidikan agama Islam adalah upaya pendidikan agama Islam atau ajaran Islam dan nilai-nilainya agar menjadi way of life (pandangan hidup dan sikap hidup) seseorang. Dalam pengertian yang kedua ini pendidikan agama Islam dapat berwujud;

1. Segenap kegiatan yang dilakukan oleh seseorang atau suatu lembaga untuk membantu seseorang atau sekelompok peserta didik dalam menanamkan agama Islam atau menumbuhkembangkan ajaran Islam dan nilai-nilainya dalam diri dan kehidupannya.

2. Segenap fenomena atau peristiwa perjumpaan dua orang atau lebih yang dampaknya ialah tertanamnya nilai-nilai ajaran Islam dan atau tumbuhkembangnya ajaran Islam dan nilai-nilainya pada salah satu atau beberapa pihak.

Menelaah pendapat beberapa ahli mengenai pendidikan Islam di atas, dapat diketahui bahwa pendidikan Islam tidak hanya diterapkan dalam lembaga pendidikan formal, tetapi juga dialami melalui proses pengalaman pribadi. Oleh karena itu, penulis menyimpulkan bahwa pendidikan agama Islam adalah proses penanaman nilai-nilai

\footnotetext{
${ }^{33}$ Mukarromah, Pendidikan Islam Integratif Berbasis Karakter (Yogyakarta: Penerbit Rubrik)

${ }^{34}$ Ibid, hal. 36
} 2018, hal. 1 
keislaman terhadap seseorang melalui metode pengajaran atau pengalaman yang terjadi di dalam atau di luar lembaga pendidikan.

E. Tujuan Pendidikan Agama Islam

Tujuan adalah sesuatu yang diharapkan setelah sebuah usaha atau kegiatan selesai dilaksanakan. ${ }^{35}$ Pendidikan agama Islam dalam satuan pendidikan dalam prosesnya memiliki tujuan sebagai fokus utama yang hendak dicapai.

Menurut Ibnu Khaldun, tujuan pendidikan Islam berorientasi $u k h r a w i$ dan duniawi. Pendidikan Islam harus membentuk manusia yang taat kepada Allah dan mampu menghadapi segala bentuk persoalan kehidupan.

Menurut Muhammad Athiyah Al-Abrasyi, tujuan tertinggi pendidikan Islam adalah tercapainya akhlak yang sempurna. Ahmad D Marimba mengemukakan bahwa pendidikan Islam adalah terbentuknya kepribadian muslim. ${ }^{36}$

Pendidikan Islam juga bertujuan untuk menjadikan manusia sebagai hamba Allah dan menciptakan aspek-aspek kepribadian seperti spiritual, intelektual, rasional, perasaan, dan kepekaan tubuh manusia. Hal tersebut seperti dikemukakan oleh Robiatul Awwaliah dan Hasan Baharun sebagai berikut:

Hakikat tujuan pendidikan Islam adalah untuk menjadikan manuisa sebagai 'abdi Allah atau hamba Allah. Pendidikan seharusnya bertujuan menciptakan pertumbuhan yang seimbang dari kepribadian total manusia yakni dengan berbagai latihan spiritual, intelektual, rasional, perasaan bahkan kepekaan tubuh manusia. Oleh karena itu, pendidikan semacam ini memerlukan suatu usaha dan pemikiran yang keras dan serius dalam upaya mewujudkan cita-citanya. ${ }^{37}$

Menelaah beberapa pendapat mengenai tujuan pendidikan Islam di atas, dapat disimpulkan bahwa tujuan pendidikan Islam adalah menjadikan manusia taat kepada penciptanya serta mampu membentuk dan mengembangkan kepribadiannya agar mampu menghadapi problematika kehidupan. Selanjutnya, pendidikan agama Islam dalam satuan pendidikan formal di Indonesia dikemukakan Badrut Tamami sebagai berikut:

Pendidikan agama Islam adalah upaya sadar dan terencana dalam menyiapkan peserta didik untuk mengenal, memahami, menghayati, hingga mengimani ajaran Islam, dibarengi dengan tuntunan untuk menghormati penganut agama lain dalam hubungannya dengan kerukunan antar umat beragama hingga terwujud kesatuan dan persatuan bangsa. ${ }^{38}$

${ }^{35}$ Miftahur Rohman \& Hairudin, Konsep Tujuan Pendidikan Islam Perspektif Nilai-Nilai Sosial Kultural, Al-Tadzkiyyah: Jurnal Pendidikan Islam, Vol. 9, No. 1, 2018, hal. 25

${ }^{36}$ Halid Hanafi; La Adu; Zainuddin, Ilmu Pendidikan Islam (Yogyakarta: Penerbit Deepublish) 2018, hal. 59

${ }^{37}$ Robiatul Awwaliyah \& Hasan Baharun, Pendidikan Islam dalam Sistem Pendidikan Nasional (Telaah Epistemologi terhadap Problematika Pendidikan Islam, Jurnal Ilmiah DIDAKTIKA, Vol. 19, N0. 1, 2018, hal. 39

${ }^{38}$ Badrut Tamami, Peran Guru Pendidikan Agama Islam terhadap Pendidikan Karakter Siswa di SMA Sultan Agung Kasiyan-Puger-Jember Tahun Pelajaran 2016/2017, TARLIM: Jurnal Pendidikan Agama Islam, Vol. 1, No. 1 2018, hal. 24 
Penjelasan tersebut dapat dimaknai bahwa pendidikan agama Islam di sekolah bertujuan untuk menjadikan peserta didik mengenal, memahami, menghayati, dan mengimani ajaran Islam. Perwujudan dari pembentukan kepribadian tersebut akan memunculkan sikap saling menghormati dan membentuk perilaku sosial di lingkungannya.

Berdasarkan tujuan pendidikan Islam secara umum serta pendidikan agama Islam dalam satuan pendidikan formal, dapat diartikan bahwa pendidikan Islam memiliki tujuan terhadap pembentukan iman, akal, dan kepribadian berlandaskan Islam agar mampu menjalani kehidupan dengan baik. Dari ketiga aspek yang dikembangkan tersebut, akhlak atau kepribadian merupakan tujuan tertinggi dari pelaksanaan pendidikan agama Islam.

F. Pengertian Karakter dan Pengembangan Karakter

Dalam Kamus Besar Bahasa Indonesia (KBBI), istilah “karakter" diartikan sebagai sifat-sifat kejiwaan, akhlak atau budi pekerti yang membedakan seseorang dari yang lain. Karakter juga bisa disebut dengan tabiat atau watak. ${ }^{39}$

Menurut Suyadi, karakter adalah nilai-nilai universal perilaku manusia yang meliputi seluruh aktivitas kehidupan, baik yang berhubungan dengan Tuhan, sesama manusia, maupun dengan lingkungan yang terwujud dalam pikiran, sikap, perasaan, dan perbuatan berdasarkan norma-norma agama, hukum, tata krama, budaya, dan adat istiadat. Karakter atau akhlak terbentuk dalam diri seseorang dari pengalaman sejak lahir. $^{40}$

Menurut Nanda Ayu Setiawati, karakter merupakan nilai-nilai khas baik yang terpatri dalam diri dan terwujud dalam perilaku. Artinya, seseorang bisa dikatakan berkarakter bila mampu mengaplikasikan nilai-nilai kebaikan yang tertanam dalam dirinya pada perilaku sehari-hari. ${ }^{41}$

Berdasarkan beberapa pengertian tersebut, penulis menyimpulkan bahwa karakter merupakan perilaku hasil bentukan dari peristiwa atau penyesuaian diri terhadap keadaan yang dialami sejak lahir. Karakter dapat diartikan sebagai perilaku khas yang menyangkut hubungan dengan Tuhan, manusia, serta lingkungan yang terwujud dalam sikap dan perbuatan.

Dalam Kamus Besar Bahasa Indonesia (KBBI), "pengembangan" diartikan sebagai proses, cara, dan perbuatan, atau pembangunan secara bertahap dan teratur yang menjurus ke sasaran yang dikehendaki. ${ }^{42}$ Dalam kaitannya dengan karakter, pengembangan dapat

\footnotetext{
${ }^{39}$ Tim Penyusun, Kamus Besar Bahasa Indonesia, (Jakarta: Badan Pengembangan Bahasa dan Perbukuan, Kementerian Pendidikan dan Kebudayaan Indonesia) 2016-2019

${ }^{40}$ Suyadi, Strategi Pembelajaran Pendidikan Karakter (Bandung: PT. Remaja Rosdakarya), 2013, hal. 5-6

${ }^{41}$ Nanda Ayu Setiawati, Pendidikan Karakter Sebagai Pilar Pembentukan Karakter Bangsa, Prosiding Seminar Nasional Tahunan Fakultas Ilmu Sosial Universitas Negeri Medan Tahun 2017, Vol. 1, No. 2017, 2017, hal 348

42 Tim Penyusun, Kamus Besar Bahasa Indonesia, (Jakarta: Badan Pengembangan Bahasa dan Perbukuan, Kementerian Pendidikan dan Kebudayaan Indonesia) 2016-2019
} 
diartikan sebagai sebuah proses pembentukan atau pendidikan yang bertujuan untuk membentuk nilai-nilai karakter dalam diri seseorang.

Secara lebih rinci Berkowitz dan Bier menjelaskan bahwa pendidikan karakter merupakan penciptaan lingkungan sekolah yang membantu siswa dalam perkembangan etika, tanggung jawab melalui model, dan pengajaran karakter yang baik melalui nilainilai universal. Nilai-nilai karakter tersebut harus ditanamkan dalam diri peserta didik dan diterapkan dalam kehidupannya. ${ }^{43}$ Di samping itu, Suyadi mengemukakan bahwa pendidikan karakter adalah upaya sadar dan terencana dalam mengetahui kebenaran atau kebaikan, mencintainya, dan melakukannya dalam kehidupan sehari-hari. ${ }^{44}$

Berdasarkan pendapat beberapa ahli mengenai pendidikan karakter, penulis menyimpulkan bahwa pendidikan karakter adalah sebuah proses atau upaya sadar dan terencana yang bertujuan untuk menanamkan nilai-nilai karakter dalam diri seseorang. Oleh karena itu, dapat dipahami bahwa pengembangan karakter adalah proses pendidikan yang dilakukan sebagai upaya penanaman nilai-nilai kepribadian yang baik dalam diri seseorang hingga dapat diterapkan dalam kehidupan.

\section{G. Implementasi Pendidikan Karakter di Sekolah}

Terbentuknya karakter yang baik dalam diri peserta didik adalah tujuan utama dari pelaksanaan pendidikan nasional di Indonesia. Oleh karena itu, diperlukan upaya yang optimal dari komponen penyelenggara pendidikan demi mencapai tujuan pendidikan tersebut.

Diperlukan pendekatan yang efektif sebagai upaya pengembangan karakter di sekolah. Dalam Dalimunthe, pendidikan karakter dapat dilakukan dengan empat pendekatan. Pendekatan yang dimaksud yaitu:

1. Pendekatan Instruktif-struktural

Strategi pembentukan karakter sudah menjadi komitmen dan kebijakan pemimpin sekolah sehingga lahir berbagai peraturan atau kebijakan yang mendukung berbagai kegiatan berkarakter di sekolah serta berbagai sarana prasarana pendukungnya termasuk dari sisi pembiasaan.

2. Pendekatan Formal-kurikuler

Strategi pembentukan karakter di sekolah dilakukan dalam pengintegrasian dan pengoptimalan Kegiatan Belajar Mengajar (KBM) di semua mata pelajaran dan karakter yang dikembangkan.

3. Pendekatan Mekanik-fragmented

Strategi pembentukan karakter di sekolah didasari oleh pemahaman bahwa kehidupan terdiri dari berbagai aspek dan pendidikan dipandang sebagai

\footnotetext{
${ }^{43}$ Binti Maunah, Implementasi Pendidikan Karakter dalam Pembentukan Kepribadian Holistik Siswa, Jurnal Pendidikan Karakter, Tahun V, No. 1, 2015, hal. 91

${ }^{44}$ Suyadi, Strategi Pembelajaran Pendidikan Karakter (Bandung: PT. Remaja Rosdakarya), 2013, hal. 6
} 
penanaman dan pengembangan seperangkat nilai kehidupan yang masingmasing bergerak dan berjalan menurut fungsinya.

4. Pendekatan Organik-sistematis

Pendidikan karakter merupakan kesatuan atau sebagai sistem sekolah yang berusaha mengembangkan pandangan atau semangat hidup berbasisnilai dan etika, yang dimanifestasikan dalam sikap hidup, perilaku, dan keterampilan hidup yang berkarakter bagi seluruh warga sekolah. ${ }^{45}$

Menelaah ke empat pendekatan tersebut, dapat disimpulkan bahwa pengembangan karakter harus bermula dari kesadaran dan komitmen kepala sekolah terhadap pentingnya pembentukan karakter yang kemudian diwujudkan melalui peraturan dan kebijakan. Peraturan dan kebijakan tersebut diberlakukan dengan kerja sama antar komponen penyelenggara pendidikan. Kemudian, pendidikan karakter dimanifestasikan dalam kegiatan pembelajaran di kelas sebagai kegiatan pertemuan langsung antara pendidik dan peserta didik sehingga upaya pendidikan tersebut berjalan efektif. Penyelenggara pendidikan harus menyadari betul pentingnya pembentukan karakter yang merupakan tujuan utama dari dilaksanakannya pendidikan.

Optimalisasi pengembangan karakter dalam satuan pendidikan kemudian dapat dilakukan melalui sosialisasi ke stakeholders (komite sekolah, masyarakat, lembagalembaga) dan pengembangan dalam kegiatan sekolah. ${ }^{46}$ Hal tersebut bermakna bahwa program pengembangan karakter yang optimal dalam satuan pendidikan membutuhkan kontribusi masyarakat dan lembaga di luar sekolah, karena keduanya dapat memberikan kritik dan masukan terkait dengan upaya sekolah dalam pengembangan karakter.

Dalam Maunah, pengembangan karakter di sekolah harus menerapkan sepuluh prinsip. Prinsip yang dimaksud adalah sebagai berikut:

Pertama, mempromosikan nilai-nilai dasar etika sebagai basis karakter. Kedua, mengidentifikasi karakter secara komprehensif supaya mencakup pemikiran, perasaan, dan perilaku. Ketiga, menggunakan pendekatan yang tajam, proaktif dan efektif untuk membangun karakter. Keempat, menciptakan komunitas yang mempunyai kepedulian. Kelima, memberi kesempatan kepada siswa untuk menunjukkan perilaku yang baik. Keenam, memiliki cakupan terhadap kurikulum yang bermakna dan menantang yang menghargai semua siswa, membangun karakter mereka, dan membantu untuk sukses. Ketujuh, mengusahakan tumbuhnya motivasi diri pada para siswa. Kedelapan memfungsikan seluruh staf sekolah sebagai komunitas moral yang berbagi tanggung jawab untuk pendidikan karakter dan setia pada nilai dasar yang sama. Kesembilan, memfungsikan keluarga dan anggota masyarakat sebagai mitra dalam usaha membangun

\footnotetext{
${ }^{45}$ Reza Armin Abdullah Dhalimunte, Strategi dan Implementasi Pelaksanaan Pendidikan Karakter di SMP N 9 Yogyakarta, Jurnal Pendidikan Karakter, Tahun V, No. 1, 2015, hal. 107-18

${ }^{46}$ Daryanto \& Suryatri Darmiatun, Impementasi Pendidikan Karakter di Sekolah (Yogyakarta: Penerbit Gava Media) 2013, hal. 74
} 
karakter. Kesepuluh, mengevaluasi karakter sekolah, fungsi staf sekolah sebagai guruguru karakter dan manifestasi karakter positif dalam kehidupan siswa. ${ }^{47}$

Penjelasan di atas memiliki makna bahwa lembaga pendidikan harus melaksanakan pendidikan karakter dengan optimal. Program dan upaya yang terkait dengan pengembangan karakter dapat dilakukan di dalam dan di luar Kegiatan Belajar Mengajar $(\mathrm{KBM})$. Kesadaran dan kerja sama antar komponen penyelenggara pendidikan memiliki peran sangat penting, karena selain menjadi penentu keberhasilan, penyelenggara pendidikan juga menjadi contoh perwujudan karakter baik yang dinilai oleh peserta didik.

Menyimpulkan beberapa hal mengenai implementasi pengembangan karakter dalam satuan pendidikan yang telah dikemukakan beberapa ahli, dapat dipahami bahwa pembentukan karakter adalah fokus utama atas dilaksanakannya pendidikan. Sistem, pendekatan, dan strategi sangat dibutuhkan dalam pelaksanaan pendidikan karakter. Di luar itu, hal terpenting adalah kerja sama dan sinergi antar komponen penyelenggara pendidikan dalam upaya pengembangan karakter tersebut. Optimalisasi pengembangan karakter dalam satuan pendidikan harus terus dilakukan sebagai salah satu kontribusi positif bagi kemajuan peradaban bangsa.

\section{HASIL PENELITIAN DAN PEMBAHASAN}

\section{A. Pelaksanaan Program Bimbingan Konseling dalam Pengembangan Karakter Siswa di SMK Negeri 1 Gunungputri}

Bimbingan dan Konseling merupakan salah satu unit yang dimiliki SMK Negeri 1 Gunungputri. Bimbingan dan Konseling di SMK Negeri 1 Gunungputri memiliki visi terwujudnya kehidupan kemanusiaan yang membahagiakan melalui tersedianya pelayanan bantuan dalam pemberian dukungan perkembangan dan pengentasan masalah agar peserta didik berkembang secara optimal, mandiri, dan bahagia. Visi tersebut dijabarkan melalui tiga misi sebagai berikut:

1. Misi Pendidikan

Misi pendidikan memfasilitasi pengembangan peserta didik melalui pembentukan perilaku efektif normatif dalam kehidupan keseharian dan masa depan.

2. Misi Pengembangan

Misi pengembangan memfasilitasi pengembangan potensi dan kompetensi peserta didik di dalam lingkungan sekolah, keluarga, dan masyarakat.

3. Misi Pengentasan Masalah

Misi pengentasan masalah memfasilitasi pengentasan masalah peserta didik, mengacu pada kehidupan efektif sehari-hari.

${ }^{47}$ Binti Maunah, Implementasi Pendidikan Karakter dalam Pembentukan Kepribadian Holistik Siswa, Jurnal Pendidikan Karakter, Tahun V, No. 1, 2015, hal. 93 
Sebagai upaya perwujudan visi misi tersebut, Bimbingan dan konseling di SMK Negeri 1 Gunungputri memiliki empat komponen program bimbingan dan konseling. Empat komponen program tersebut yaitu layanan dasar, layanan responsif, layanan peminatan dan perencanaan individual, serta dukungan sistem.

Layanan dasar meliputi bimbingan klasikal, bimbingan kelas besar atau lintas kelas seperti seminar, bimbingan kelompok (di luar kegiatan klasikal), dan penyampaian informasi melalui media informasi seperti "Papan Bimbingan" yang berbentuk majalah dinding. Selain itu informasi juga disampaikan melalui media sosial seperti Instagram dan facebook. Layanan Responsif meliputi layanan konseling individual untuk peserta didik yang bermasalah, konseling kelompok, dan konsultasi, serta konferensi kasus jika ada permasalahan yang harus dibicarakan bersama. Selain itu, Bimbingan dan konseling di SMK Negeri 1 Gunungputri juga menyediakan layanan home visit atau kunjungan rumah, dan alih tangan kasus bila ada permasalahan yang tidak bisa ditangani atau di luar kewenangan Bimbingan dan konseling. Bimbingan dan konseling juga melakukan advokasi atau pendampingan bagi peserta didik yang membutuhkan bantuan bila ada hak asasi yang tercederai.

Layanan peminatan dan perencanaan individual meliputi kegiatan kurikuler maupun akomodasi terkait minat dan bakat. Kegiatan ini dilakukan seperti layanan dasar, namun ditambah dengan kolaborasi dengan guru mata pelajaran, psikolog, dan industri. Layanan peminatan dan perencanaan individual ini mengarahkan peserta didik, khususnya tingkat akhir untuk melanjutkan studi, bekerja di industri, atau berwirausaha. Program besar dari layanan ini adalah "Career Day" yang mengakomodir peserta didik agar lebih bisa melihat arah masa depannya sesuai dengan minat dan bakat.

Komponen program lainnya adalah dukungan sistem yang meliputi kegiatankegiatan seperti pelatihan guru bimbingan dan konseling. Di samping itu, kegiatan dalam komponen program dukungan sistem ini adalah penyiapan sarana dan prasarana agar program bimbingan dan konseling berjalan dengan optimal. Hal tersebut dilakukan melalui pengajuan permohonan kepada pihak sekolah terkait sarana dan prasarana yang dibutuhkan.

Program-program tersebut menjadi rutinitas yang terus diupayakan untuk dilaksanakan sebagaimana mestinya, kendalanya adalah antusiasme atau respon peserta didik yang tidak sesuai harapan, misalnya dalam kegiatan "Career Day" yang sering kali tidak diikuti oleh semua peserta didik tingkat akhir. Hal tersebut menjadi evaluasi bagi bimbingan dan konseling di SMK Negeri 1 Gunungputri untuk mengemas programprogram yang dijalankan menjadi lebih menarik.

Dalam upaya pengembangan karakter, bimbingan dan konseling di SMK Negeri 1 Gunungputri juga memberikan masukan kepada sekolah yang akhirnya melahirkan sebuah program seperti kegiatan MPLS (Masa Pengenalan Lingkungan Sekolah) yang menghadirkan KORAMIL (Komando Rayon Militer) untuk ikut berpartisipasi demi tercapainya pendidikan karakter, khususnya sisi kedisiplinan. Selain itu, program berbasis 
karakter lainnya diwujudkan melalui training motivasi. Bimbingan dan konseling juga sering melakukan kolaborasi dengan guru agama untuk menjalankan upaya pembentukan sikap religius pada peserta didik.

Upaya pembentukan sikap religius juga diupayakan melalui kegiatan-kegiatan pembiasaan. Kegiatan pembiasaan tersebut berbentuk punishment berupa ibadahbagi siswa yang melakukan kesalahan. Upaya-upaya pengembangan karakter tersebut secara berproses akhirnya bisa menghasilkan perubahan positif pada karakter peserta didik.

\section{B. Upaya Guru Pendidikan Agama Islam dalam Pengembangan Karakter Siswa di SMK Negeri 1 Gunungputri}

Guru pendidikan agama Islam di SMK Negeri 1 Gunungputri sangat menekankan pendidikan karakter pada peserta didik, di samping mengajarkan ketaatan kepada Allah Swt. Penanaman nilai-nilai karakter yang baik diajarkan melalui metode ceramah dan diskusi.

Pembelajaran pendidikan agama Islam selalu dimulai dengan pembacaan AlQur'an. Selain untuk menyadarkan pentingnya Al-Qur'an sebagai pedoman bagi seorang muslim, hal ini juga ditujukan untuk mengentaskan buta huruf Al-Qur'an pada peserta didik. Meskipun dalam masa pandemi yang mengharuskan kegiatan pembelajaran dilakukan melalui jaringan internet, pembacaan Al-Qur'an menjadi kegiatan pembukaan yang tidak boleh dilewatkan.

Materi yang diajarkan untuk pengembangan karakter adalah materi tentang akhlak. Materi tersebut tidak hanya diajarkan sebagai kewajiban belajar di kelas saja, melainkan harus diaplikasikan dalam kehidupan sehari-hari.

Guru pendidikan agama Islam di SMK Negeri 1 Gunungputri juga memiliki peran keagamaan di luar mata pelajaran. Guru pendidikan agama Islam menjadi tenaga untuk mengajak peserta didik melakukan ibadah salat dhuha yang telah dibiasakan setiap hari di SMK Negeri 1 Gunungputri. Guru-guru pendidikan agama Islam memeriksa setiap kelas untuk memastikan bahwa semua peserta didik yang beragama Islam sudah ikut melaksanakan salat dhuha bersama. Ajakan tersebut juga berlaku di setiap salat wajib.

Salah satu kendala dalam upaya pengembangan karakter yang dilakukan guru pendidikan agama Islam adalah kurangnya personil untuk memeriksa kelas di setiap waktu salat wajib. SMK Negeri 1 Gunungputri memiliki jumlah peserta didik lebih dari seribu orang, sehingga tidak cukup hanya guru pendidikan agama Islam saja yang bergerak keliling kelas.

Guru pendidikan agama Islam juga sering melakukan kolaborasi dengan guru bimbingan dan konseling jika menemukan masalah pada peserta didik yang tidak lagi bisa ditangani. Kolaborasi tersebut juga berjalan pada bidang lain seperti pada program PHBI (Peringatan Hari Besar Islam) yang rutin dilaksanakan oleh sekolah.

\section{Bentuk Kerja Sama guru Pendidikan Agama Islam dan Bimbingan Konseling dalam Pengembangan Karakter Siswa di SMK Negeri 1 Gunungputri}


SMK Negeri 1 Gunungputri adalah sekolah menengah kejuruan yang sangat menitikberatkan karakter dalam pelaksanaan pendidikannya. Kedisiplinan dan religiusitas adalah dua hal yang paling ditekankan dan menjadi ciri khas SMK Negeri 1 Gunungputri. Hal tersebut bisa dilihat dari pembiasaan salat dhuha yang dilaksanakan sebelum kegiatan pembelajaran berlangsung, penekanan kepatuhan terhadap salat wajib, dan pelaksaaan wajib pramuka bagi seluruh siswa baru selama satu semester, peraturan rambut cepak bagi laki-laki, juga kewajiban mengikuti kegiatan ekstrakulikuler bagi seluruh peserta didik.

Dua komponen sekolah yang memiliki peran penting dalam pendidikan karakter tersebut adalah guru pendidikan agama Islam dan bimbingan konseling. Kedua komponen tersebut sudah melakukan kerja sama dalam pengembangan karakter, khususnya kedisiplinan dan religius.

Bentuk kerja sama guru pendidikan agama Islam dan bimbingan konseling di SMK Negeri 1 Gunungputri adalah interaksi dan saling memberikan dukungan, bahkan berkolaborasi dalam satu program yang diadakan sekolah. Sinergi yang terjalin bukan hanya sebatas interaksi dan dukungan verbal, tetapi secara optimal melakukan upayaupaya di luar mata pelajaran mengentaskan permasalahan karakter peserta didik secara bersama-sama.

\section{Sinergitas Bimbingan Konseling dan Guru Pendidikan Agama Islam dalam \\ Pengembangan Karakter Siswa di SMK Negeri 1 Gunungputri}

Melihat hasil temuan penelitian, penulis dapat menyimpulkan bahwa kerja sama antara bimbingan konseling dan guru pendidikan agama Islam berjalan dengan baik dan menunjukkan keberhasilan. Guru pendidikan agama Islam ikut berkontribusi bagi program-program bimbingan konseling, begitupun sebaliknya. Bimbingan konseling dan guru pendidikan agama Islam SMK Negeri 1 Gunungputri memiliki kualitas yang baik, hal tersebut dapat dijabarkan melalui beberapa hal.

1. Konsep dan perencanaan bimbingan konseling baik dan lengkap. Hal tersebut dapat dilihat dari data program layanan bimbingan dan evaluasi bimbingan konseling SMK Negeri 1 Gunungputri.

2. Personil bimbingan konseling di SMK Negeri 1 Gunungputri memiliki jumlah yang cukup dan memiliki kompetensi yang sesuai, bimbingan konseling di sekolah tersebut memiliki lima personil dengan latar belakang pendidikan bimbingan konseling.

3. Sarana dan prasarana bimbingan konseling di SMK Negeri 1 Gunungputri lengkap, begitupun ruangan bimbingan konseling sesuai standar Permendikbud No 111 Tahun 2014 tentang Bimbingan dan Konseling pada Pendidikan Dasar dan Menengah.

4. Program-program yang dilaksanakan bimbingan konseling di SMK Negeri 1 Gunungputri berjalan dengan baik dan memberikan dampak positif bagi peserta didik. 
5. Guru pendidikan agama Islam melakukan kegiatan pembelajaran yang baik dan selalu menekankan nilai-nilai akhlakul karimah pada peserta didik.

6. Guru pendidikan agama Islam menjalankan peran keagamaan dan menjalankan tanggung jawab pendidikan karakter di luar jam pelajaran.

7. Guru pendidikan agama Islam turut berpartisipasi dalam beberapa kegiatan bimbingan dan konseling.

8. Bimbingan konseling dan guru pendidikan agama Islam menjalin kerja sama dalam setiap program yang dilaksanakan oleh sekolah yang berhubungan dengan pendidikan karakter.

9. Sekolah memandang baik kinerja bimbingan konseling dan pendidikan agama Islam di SMK Negeri 1 Gunungputri dalam pengembangan karakter.

10. Siswa merasakan pengaruh positif dari program-program bimbingan konseling dan upaya guru pendidikan agama Islam dalam pengembangan karakter.

Melihat dari sepuluh alasan tersebut, penulis dapat menyimpulkan bahwa sinergitas program bimbingan konseling dan guru pendidikan agama Islam di SMK Negeri 1 Gunungputri memiliki kualitas yang baik. Kendala dan kekurangan yang didapatkan hanya dari kurangnya personil sekolah untuk membantu mewujudkan penanaman nilainilai religius dan kesadaran sebagian peserta didik dalam memahami pentingnya nilainilai karakter dalam kehidupan.

\section{SIMPULAN}

Berdasarkan hasil penelitian tentang sinergitas bimbingan konseling dan guru pendidikan agama Islam dalam pengembangan karakter di SMK Negeri 1 Gunungputri, penulis dapat menguraikan beberapa kesimpulan sebagai berikut:

1. Pelaksanaan program bimbingan dan konseling dalam pengembangan karakter siswa di SMK Negeri 1 Gunungputri menunjukkan hasil positif. Programprogram yang dijalankan berkonsentrasi pada pendidikan karakter dengan beragam kegiatan dan persiapan yang matang. Kegiatan yang dilaksanakan oleh bimbingan dan konseling di SMK Negeri 1 Gunungputri memiliki perencanaan yang baik dan personil yang kompeten, sehingga tujuan pelaksanaan program dapat tercapai. Kendala yang dihadapi adalah persepsi siswa akan bimbingan dan konseling yang masih memiliki yang salah terhadap bimbingan dan konseling (dianggap galak dan sebagainya).

2. Guru pendidikan agama Islam di SMK Negeri 1 Gunungputri sangat menekankan pendidikan karakter di dalam dan di luar mata pelajaran. Pendidikan karakter religius dalam kelas dilakukan dengan mewajibkan seluruh peserta didik yang beragama Islam untuk membaca Al-Qur'an sebelum dilangsungkan kegiatan pembelajaran. Di luar mata pelajaran, guru pendidikan 
agama Islam melakukan pendidikan karakter dengan menegur peserta didik yang melanggar peraturan. Di samping itu, guru pendidikan agama Islam ikut berkontribusi dalam kegiatan bimbingan dan konseling, serta berkeliling kelas menjemput peserta didik untuk melaksanakan salat wajib dan salat dhuha. Kendala yang ditemukan adalah kurangnya personil yang ditugaskan untuk berkeliling kelas pada waktu salat wajib dan salat dhuha.

3. Sinergi program bimbingan konseling dengan guru pendidikan agama Islam di SMK Negeri 1 Gunungputri berjalan dengan baik. Selain dengan interaksi, bentuk kerja sama bimbingan konseling dan guru pendidikan agama Islam di SMK Negeri 1 Gunungputri juga dilakukan melalui program sekolah terkait pendidikan karakter. Di samping itu, guru pendidikan agama Islam juga sering membantu bimbingan konseling dalam menyelesaikan permasalahan peserta didik.

\section{Saran}

Terkait dengan penelitian, pembahasan, dan kesimpulan sinergitas bimbingan konseling dan guru pendidikan agama Islam dalam pengembangan karakter di SMK Negeri 1 Gunungputri yang menunjukkan hasil positif, diperlukan saran atau rekomendasi kepada berbagai pihak sebagai berikut:

1. Program dan kegiatan bimbingan konseling di SMK Negeri 1 Gunungputri sudah berjalan dengan baik, maka diperlukan konsistensi dan peningkatan. Kendala tentang kurangnya partisipasi dan pemahaman peserta didik pada bimbingan konseling maupun program yang dijalankan hendaknya menjadi bahan evaluasi agar bimbingan konseling bisa mengemas program dengan lebih menarik. Kesalahan persepsi peserta didik terhadap bimbingan konseling perlu diluruskan, sehingga peserta didik tidak lagi takut pada guru bimbingan konseling.

2. Guru pendidikan agama Islam di SMK Negeri 1 Gunungputri telah melalukan upaya maksimal terhadap pendidikan karakter. Oleh karena itu, sekolah harus memberikan dukungan dan apresiasi terhadap guru pendidikan agama Islam. Tambahan personil dibutuhkan untuk membantu guru pendidikan agama Islam melaksanakan tugasnya pada waktu salat.

3. Guru pendidikan agama Islam SMK Negeri 1 Gunungputri harus terus melakukan evaluasi terhadap kegiatan pembelajaran untuk pengembangan dan peningkatan gaya mengajar setiap harinya. Pengembangan metode pembelajaran juga perlu dilakukan agar kegiatan pembelajaran di kelas semakin menyenangkan sehingga nilai-nilai keagamaan yang diberikan dapat dengan mudah diterima.

4. Peserta didik di SMK Negeri 1 Gunungputri perlu bersikap aktif dan responsif terhadap tujuan dan program sekolah. Partisipasi terhadap program bimbingan konseling juga harus ditingkatkan demi kebaikan bersama. Di samping itu, peserta didik hendaknya mampu memahami bahwa pendidikan bukan hanya terdapat dalam pembelajaran saja, tetapi juga pada sikap dan perilaku seharihari. 


\section{DAFTAR PUSTAKA}

Azam, U. (2016). Bimbingan dan Konseling Perkembangan di Sekolah Teori dan Praktik. Yogyakarta: Penerbit Deepublish.

Darimunthe, R. A. (2015). Strategi dan Implementasi Pelaksanaan Pendidikan Karakter di SMP N 9 Yogyakarta. Jurnal Pendidikan Karakter, 107-108.

Daryanto, D., \& Suryatri Darmiatun, S. M. (2013). Impementasi Pendidikan Karakter di Sekolah. Yogyakarta: Penerbit Gava Media.

Hanafi, H., Adu, L., \& Zainuddin. (2018). Ilmu Pendidikan Islam. Yogyakarta: Penerbit Deepublish.

Maunah, B. (2015). Implementasi Pendidikan Karakter dalam Pembentukan Kepribadian Holistik Siswa. Jurnal Pendidikan Karakter, 91.

Mukarromah. (2018). Pendidikan Islam Integratif Berbasis Karakter. Yogyakarta: Penerbit Rubrik.

Rohman, M., \& Hairudin. (2018). Konsep Tujuan Pendidikan Islam Perspektif Nilai-Nilai Sosial Kultural. Al-Tadzkiyyah: Jurnal Pendidikan Islam, 24.

Rukajat, A. (2018). Pendekatan Penelitian Kualitatif (Qualitative Research Approach). Yogyakarta: Penerbit Deepublish.

Satriah, L. (2018). Panduan Bimbingan dan Konseling Pendidikan. Bandung: FOKUSMEDIA.

Sriyono, H. (2015). Bimbingan dan Konseling Belajar Bagi Siswa di Sekolah. Depok: PT Raja Grafindo Persada.

Suyadi, M. (2013). Strategi Pembelajaran Pendidikan Karakter. Bandung: PT. Remaja Rosdakarya.

Tamami, B. (2018). Peran Guru Pendidikan Agama Islam terhadap Pendidikan Karakter Siswa di SMA Sultan Agung Kasiyan-Puger-Jember Tahun Pelajaran 2016/2017. Pendidikan Islam, 24.

Tim Penyusun. (2016-2019). Kamus Besar Bahasa Indonesia. Jakarta: Badan Pengembangan Bahasa dan Perbukuan, Kementerian Pendidikan dan Kebudayaan Indonesia.

Yusuf, A.M. (2019). Metode Penelitian Kuantitatif, Kualitatif \& Penelitian Gabungan. Jakarta: PRENAMEDIA GROUP. 
Yusuf, S. (2017). Bimbingan dan Konseling Perkembangan: Suatu Perkembangan Komprehensif. Bandung: PT Refika Aditama. 